\title{
Visual Elements of Semar Calligraphy on Cirebon Glass Painting of Kusdono’s Work
}

\author{
Yayah Rukiah $^{\mathrm{a}, 1, *}$, Sarwanto $^{\mathrm{b}, 2}$, Sutarno $^{\mathrm{c}, 3,}$, Sunardi $^{\mathrm{d}, 4}$ \\ ${ }^{a}$ Lecture at Universitas Indraprasta PGRI, Jakarta, Doctoral Student at Institut Seni Indonesia, Surakarta, 57126, Indonesia \\ ${ }^{\mathrm{b}}$ Professor at Institut Seni Indonesia, Surakarta, Jl. Ki Hadjar Dewantoro No. 19 Surakarta 57126, Indonesia \\ ${ }^{\mathrm{c}}$ Professor at Institut Seni Indonesia, Surakarta, Jl. Ki Hadjar Dewantoro No. 19 Surakarta 57126, Indonesia \\ ${ }^{\mathrm{d}}$ Doctor at Institut Seni Indonesia, Surakarta, Jl. Ki Hadjar Dewantoro No. 19 Surakarta 57126, Indonesia \\ rukiah.yayah13@gmail.com*; ${ }^{2}$ sarwantosarwanto16@yahoo.com; ${ }^{3}$ tarno_dea@yahoo.com; ${ }^{4}$ gunowijoyo@gmail.com \\ * Corresponding Author
}

Received 2020-07-09; accepted 2020-07-23; published 2020-12-20

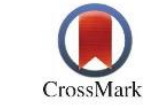

\section{KEYWORDS}

Cirebon glass painting; Semar; Calligraphy

This is an openaccess article under the CC-BY-SA

license

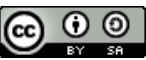

\section{Introduction}

Wayang kulit is one of the valuable heritage in Javanese society. Wayang purwa is a live human symbol in the world (Hardjowirogo 1982, 11). Indonesia is a rich country of culture. The culture that emerged and developed in every tribe has different characteristics, so every province has a unique culture, such as Javanese culture. Culture is a whole of the idea, action, and artwork in human life to be own through studying. The culture can be divided into seven elements; one of them is art. Art is one of the universal cultural elements. Art is the human expertise in their excellent artwork, from the beauty point of view, every country, tribe, even a human has an art (Probosiwi and Hastuti 2019). Anisah cites Guritno, who stated wayang is a symbol of living that has more spiritual than physical. If people watched the shadow show, they did not watch the wayang but the wayang story's moral view. Wayang purwa is known as wayang kulit or wayang kulit purwa. It happened because a lot of wayang kulit, whereas wayang kulit purwa is a puppet show where characters come from a heroic story from Ramayana and Mahabharata (India) (Anisah 2008, 1).

Karkono in Sunarto stated wayang kulit purwa in Indonesia is known in some various style, they are wayang kulit purwa Yogyakarta, wayang kulit purwa Surakarta, wayang kulit purwa Banyumasan, wayang kulit Kedhu, wayang kulit Jawa Timur, wayang kulit Bali, wayang kulit Cirebon (Sunarto 1997, 97). In various wayang kulit purwa that have some style, the characters can be differentiate. One of character of wayang kulit purwa is Punakawan or Dhagelan that have different style. Punakawan is a part of wayang in Indonesia because, in the story of a puppet in India, there is not Punakawan character. Whereas the wayang emerged before Hindus came into Indonesia and fossilized in Javanese culture. In Javanese, Semar is a peaceful and welfare symbol, and Semar is a father or Danyang of Javanese people, based on Sabdo and Nyagenggong (Kresna 2012, 47). There is no Punakawan in the Hindu mythology of Mahabarata or Ramayana epic; Punakawan is a modification of the precept of Islam by Sunan Kalijaga, though this opinion is discussed (Kresna 2012, 17). 
The Semar Punakawan figure and the shape of the wayang kulit purwa were also applied in several other visual or visual forms such as artifacts, reliefs, batik, and Cirebon glass paintings. In essence, the first to become fathers and mothers of all puppets are Hyang Manikmaya (Betara Guru) and Hyang Ismaya (Semar), compatriots of Gods (Hardjowirogo 1982, 11). The audience idolizes the art performance of Semar's puppet shows. Semar's thoughts, words, and actions are deemed appropriate to be heeded, emulated, and applied daily. Javanese people give high appreciation to Semar figures who can inspire to guide steps on the path of goodness. Semar is the most prominent punakawan figure in Javanese puppets, even in puppets in the Sunda and Bali regions. Semar, in addition to the wayang kulit purwa, is also found in reliefs such as the Sukuh temple, glass paintings in Cirebon, and so on. Cirebon has many subtle arts fields, especially painting; Cirebon has one type of art that is quite well known, namely glass painting. Unlike the general art of painting, which uses many paper and canvas media, some Cirebon artists paint using glass media. Cirebon glass painting is somewhat unique and complicated because of how to paint it upside down from the glass's backside, not the front. Besides, painting requires special skills such as accuracy, accuracy, patience, and others because every curve of the line is made upside-down. Likewise with coloring, including making gradation effects can only be done with a single sweep. Even now, along with the times, the provision of color, especially on the painting's background, is done by spray technique or airbrush. The medium is paint and glass, and some use other supporting media such as glue, sand, rope, rice grain, and others.

At the beginning of the Cirebon glass painting's existence, the themes raised were puppet themes combined with Islamic calligraphy. Cirebon glass painting was a legacy of the Panembahan Ratu government in the 17th century. The influence of Islam spread by the saints also became a characteristic of Cirebon glass paintings even after Chinese influence. The images produced by traditional artists are always associated with Islam, such as images of the Kaaba, mosque, and calligraphy containing verses of the al Qur'an. As with other traditional arts, the painting was created with different objectives to win the power or spread of religion. According to Soedjono in Waluyo (Waluyo 2006, 73), the mission of these works of art is more a suggestion of social ethics based on moral teachings Kejawen through puppet symbols, added and integrated with Islamic teachings through the verses of the al Qur'an. Glass painting is the art of painting upside down, rich in color gradations and harmonizing decorative nuances and displaying ornaments or decorative motifs of mega mendung and wadasan motifs that we know as Cirebon batik motifs. It takes a long time to learn, not because it involves painting a picture in reverse. The stages of making glass paintings are doing works painted in reverse, i.e., at the back of the glass, the design's front is the first layer seen as part of the final work.

\section{Literature Review}

The article titled iconic of Cenk and Blonk Puppet Punakawan Wayang Figures written by I Made Diana Dwi Putra, et al. explains (1) The existence of the Cenk Blonk puppet was founded in 1992 in Banjar Batanyuh Kelod, Belayu Village, Marga District, Tabanan Regency, initiated by I Wayan Nardayana, who was born in Tabanan on July 5, 1966. (2) Form and physical characteristics, character, character, non-physical characteristics and characteristics of Cenk and Blonk figure: using the horn sengki connector in the arms, mouth, and legs, using pecuntil, body frogs and hand frogs, the characteristics of the Cenk punakawan are the shape of the mouth monyong, both the upper and lower jaws can be moved, many teeth and the speech style of Cenk's clerks tend to be theoretical, the nature of Cenk's clowns are censure and criticize other clowns and are not easily defeated. The Blonk punakawan is the shape of a wide mouth, bald head, and big belly. The style of speech by Blonk speaks frankly. Blonk's character is like telling himself. (3) The Cenk and Blonk figures' function during the staging is as a pause during the war round (Putra, Sudiarta, and Ardana 2014).

This research is about Djoko Pekik's painting titled 'The Land of the Young Married, ' which is analyzed using the art history approach and uses the iconographic theory and Erwin Panofsky's iconology. The method used is the historical method to search for sources in the field and library (heuristics), selection and criticism, analysis and interpretation of sources to produce a synthesis, and compilation of historiography. This study's results include a Pre-iconographic description containing initial responses to textual aspects, revealing communication and conflict between two teachers. The iconographic analysis is about the themes and concepts of men's oppression through the power of economic, social, and cultural capital. The basic concept of its creation is the conflict between 
oppressive power and the rights that must be defended. Iconological interpretation is about symbolic values expressed in paintings. Through the painter's psychological experience with a variety of violence and suffering, as well as a view of life from his social and cultural background, this painting is a crystallization of the symbol of deprivation and defense of the rights of the underprivileged who suffer.

\section{Method}

This research is a qualitative study to uncover and identify the research object's visual elements, namely the Cirebon Kaligrafi Semar glass painting by Kusdono with an aesthetic approach. The aesthetic approach uses art as guidance and spectacle by looking at shapes in glass paintings. The shape is a structure or composition, an arrangement consisting of repetition or arrangement of patterns. The pattern consists of the main motive, filler motif (interlude), and the fill motif (Dharsono 2016, 77).

- The main motif is the main element in the form of pictures of certain forms. The main motif because it is an element the principal is often called the main ornament (main ornament).

- Filling motif (interlude motifs) are supporting elements, in the form of pictures of a particular form, made to fill the fields between the main motifs. Its function is to decorate the pattern.

- Isen (stuffing) is a filler element whose function is to decorate the main motif and interlude (supporting) motif (Dharsono 2016, 78).

Noeng Muhadjir said that conducting qualitative research is to prioritize critical abilities in observing the topic (Muhadjir 2000, 7). To examine the meaning in visual art based on Erwin Panafsky in Casande in Rukiah (Rukiah 2016), there are three stages of interpretation, namely:

- Pre-iconographical description (empirical)

Pre-Iconographic is a study of initial descriptions based on our own practical experiences regarding the shapes, lines, colors, and expressions, and sensations that we find.

- Iconographical analysis (analytic)

In this stage, we enter the world of logic by reading hypothetically, generalizing, and interpreting. Besides, we also need to capture and realize knowledge about the literary sources that we learn.

- Iconological interpretation (thematic)

At this last stage, we enter an area of human thought consisting of beliefs, assumptions, hopes, attitudes, religious and cultural values. This area of thought becomes a conclusion and interpretation of observations in its application in the space of daily life.

According to Panofsky (Panofsky, Dürer, and Vasari 1955, 39:26), finding forms and meanings contained in a work of art while knowing the background that influences the emergence of the work of art. This principle then becomes the basis for any qualitative research on practices and behaviors that shape reality (Denzin and Lincoln 2011, 336). In qualitative research, the data obtained is often unstructured and relatively numerous, allowing researchers to organize, critique, and classify the data obtained (Endraswara 2006, 15). The data source is a type of data that are distinguished based on the nature of objectivity. Data sources used in this study are primary sources and secondary sources. The primary sources in this study are experts in their fields. Secondary sources in this study are literature or textbooks relating to the object of research and other supporting documents. According to Miles \& Haberman in Lincoln (Denzin and Lincoln 2011, 592), data analysis (data analysis) consists of three sub-processes: data reduction, data presentation, and concluding/verification, and this can be seen in Figure 1. 


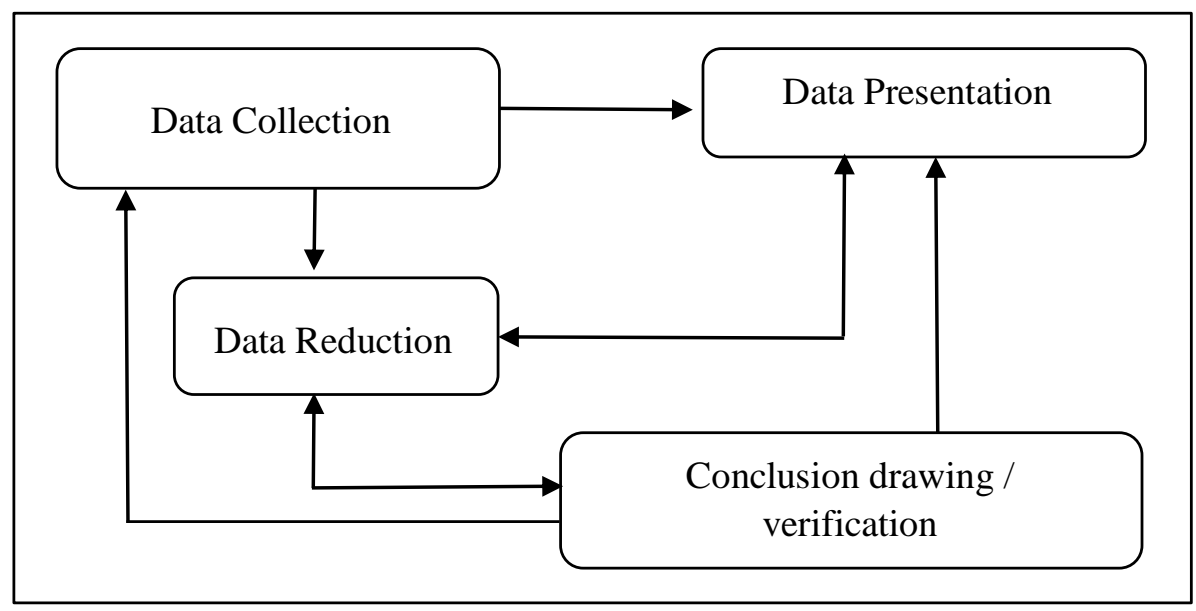

Fig. 1. Data Analysis Component (Denzin and Lincoln 2011)

\section{Results and Discussion}

In this study, researchers wanted to examine the visual elements in Kusdono's Cirebon glass painting with the theme Semar Calligraphy with an aesthetic approach, measuring $50 \mathrm{~cm} \mathrm{x} 40 \mathrm{~cm}$, see Figure 2. The narration of Kusdono's paintings is generally a depiction of good and evil, punishment and crime, angkara and samadi, in patterns and motifs derived from stories of legends and puppets, with mixed motifs between Javanese-Hinduism, Islam, and China that have been transformed.

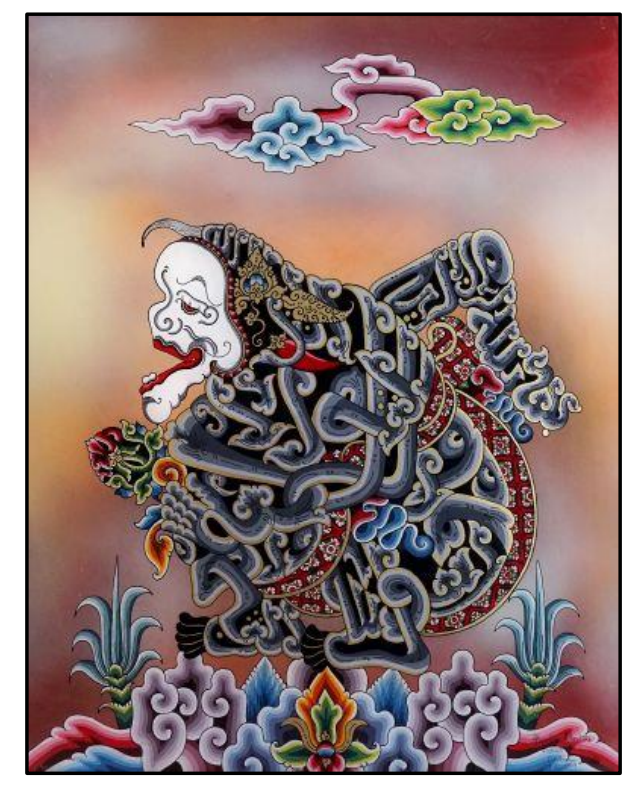

Fig. 2. Semar Calligraphy Glass Painting by Kusdono, "Semar Calligraphy," 50 x 40 cm, Glass Media, Painting Technique (Rukiah 2019)

Kusdono's works usually raise themes around folklore, wayang stories, the Cirebon people's daily situation, and the great symbols of the area, such as the Buroq (human-headed bird). The theme of Kusdono's works is divided into land, sky, and sea. This painting is a painting with a decorative, traditional style. With painting techniques using oil paint media on the glass. Semar is the name of the most prominent panakawan figure in Javanese and Sundanese puppets. This figure is told as a caregiver and an adviser to the knights in the staging of Mahabharata and Ramayana from India. 


\subsection{Pre-Iconographic Description}

The initial stage of studying the Cirebon glass painting Semar Calligraphy is a pre-iconographic description. At this stage, describing the physical identity is seen factually in the work of this painting. This glass painting in Cirebon Semar Calligraphy measures 50 x $40 \mathrm{~cm}$, with a full-color background, with a Semar in the middle of the painting. The Semar figure is formed from lines and filled with ornaments; the upper part of the painting has a motif that forms a cloud. Simultaneously, at the bottom left and right of the Semar figure, there is an ornament depicting grass. Below Semar, some rocks are made unlike stone is sharp but made round formed from motifs.

\subsection{Iconographic Analysis}

Cirebon glass painting Semar Calligraphy is referred to as figural calligraphy because it combines figural motifs with calligraphy elements through various ways and styles. In this type, many letter designs are extended, shortened, widened, slipped, or specified by expanding circles, or additional signs and other inserts that are made to fit the non-calligraphic, geometric, flora, fauna, or human figures. Cirebon glass painting with the title of Semar Calligraphy by Kusdono, there are two meanings: the subject of a pre-iconographic description that constructs the basic meanings of visual form, namely factual and expressional meanings. The real meaning is obtained from the characteristics of the shape of the object and its change from a particular event (Panofsky, Dürer, and Vasari 1955, 39:28). The real meaning in an illustration can be explored by dismantling the units or visual elements that make up the illustration as a whole. The real meaning of this Cirebon glass painting is that the illustration fills the entire space on the main panel display (PDP). The colors used in contrast are very high, i.e., a combination of gradations of blue, red, green, white, and black into one unit.

This painting has no visual supporting text. At the top of the painting or above, the Semar figure is depicted as dark clouds that form clouds with a collection of almost symmetrical parts. The position of the clouds is above Semar's head and in the middle of the painting field. The composition used is also centric, namely by placing the Semar figure at the bottom center of the painting area; Semar's face is depicted white with red lips and curved lines that form the nose, eyebrows, eyes cheeks. At the same time, Semar's body in this painting is colored in black, which contains Arabic calligraphy, which is written in two shahadat sentences. Calligraphy is colored gray gradation with gold prada. This creed calligraphy is made precisely like Semar Cirebon based on its standard, which has a difference from the Semar standard in Java (Koentjaraningrat 1990, 60-68). In some parts of Semar's body, some dots support the shape of the body. In this glass painting, on the bottom, there is an ornament that depicts rocks that do not show sharp shapes, but round and grass on the left and right Semar and supporting ornaments in the form of mega mendung, which make a balanced composition. Coloring for red to the yellow graded background. This shows an analogous gradation that is comfortable to look at, especially concerning the Semar figure's appearance. Overall, both the color composition and layout of each text and image looks harmonious and balanced to form a unified painting.

\subsection{Interpretation of Iconology}

The interpretation of iconology is the final stage in this research. Semar figure was appointed in this Cirebon glass painting to elevate identity, especially the people of Cirebon. The Semar figure's essence in the Javanese community, especially the people of Cirebon, is as a figure in the Lord right. The wayang Semar figures in wayang are panakwan or tutors who Memayu Hayuning Bawono, and Sepi Ing Pamrih, Rame Ing Gawe. Wayang Semar is one of the shadow puppet figures given God's nature or god or god to defeat God's power or Betara Guru. An argument quoted from a theologian, namely Harun Hadiwijono, who stated as follows: "... here the notion of God becomes blurred. With Plato's teachings about "divine nature" or "divinity" that was divine or god became a predictive understanding. It means an understanding that indicates the name of nature."(Hadiwijono 1983). God becomes Illahi or "divine." The proposition is not "God is divine," but "Divine is God." (that the two propositions are very different compared to the proposition that reads: Chicken is an animal, and animal is chicken). For Plato, the important thing is "the divine" or "divinity," then "the divine or" divinity "is considered God" (Mulyono 1989, 107). Semar is the figure that is most loved by the audience, and if he appears on the layer, he will receive a surge of sympathy, as if the audience is under his protection. Semar is a protective spirit that is very strong in Java, even throughout the world. Through Semar and not through mystical speculation, Javanese's relativity about the existence of the divine realm became very clear. The unique appearance of Semar without a human form is a picture 
of the divine basis as expressed in the Dewa Ruci's hymn, which states "there is no form or appearance without form and invisible" (Waluyo 2006, 99).

Semar-themed glass paintings and calligraphy turned out to be a synergy between the two forces of morality and theological ethics, namely a visual vehicle in the form of wayang and calligraphy aspects non-figurative aesthetic expression. Cirebon glass painting Semar Calligraphy is a traditional art that experienced distraction-strait if which was initially a means of Islamic da'wah. However, in terms of its form, there is a continuity of the wayang form in the Hindu period with the Islamic religion. Puppet as a performance art contains various values because of its multimedia nature. This illustrates that religious art is transformed into art as da'wah (teachings or guidance) and performance art (spectacle). Then art after the Islamic period can be called guidance and spectacle (Dharsono 2016, 77). Cirebon glass painting Semar Calligraphy is formed from the arrangement of patterns or structures that have repetition. The pattern of this Cirebon glass painting consists of: The main motive is the principal or most dominant element. In this case, the main motive is the figure of Semar. The Semar figure is the principal ornament (central ornament) because Semar contains philosophy as a guide. Semar figure in Javanese society as a greeting. Semar is a civil servant who is respected but also respects, is honest, straightforward, can accommodate and act but is also lonely (sepi ing pamrih), suwung, sunyata, taya, and empty of self-interest for his benefit, but precisely in his emptiness and emptiness that is located virtual magic and its use. Fill motif (interlude motifs) are supporting elements in pictures of specific shapes made to fill the fields between the main motifs. Usually made smaller than the primary motive, its function is to complete the layout in making patterns (Dharsono 2016, 78). In this glass painting, the filler motives are:

- In Figure 3 is Mega mendung motif found on the top or symmetrical position of Semar's head with a gradation of colors in blue, red, and green, mega mendung function here as a cloud that shade Semar.

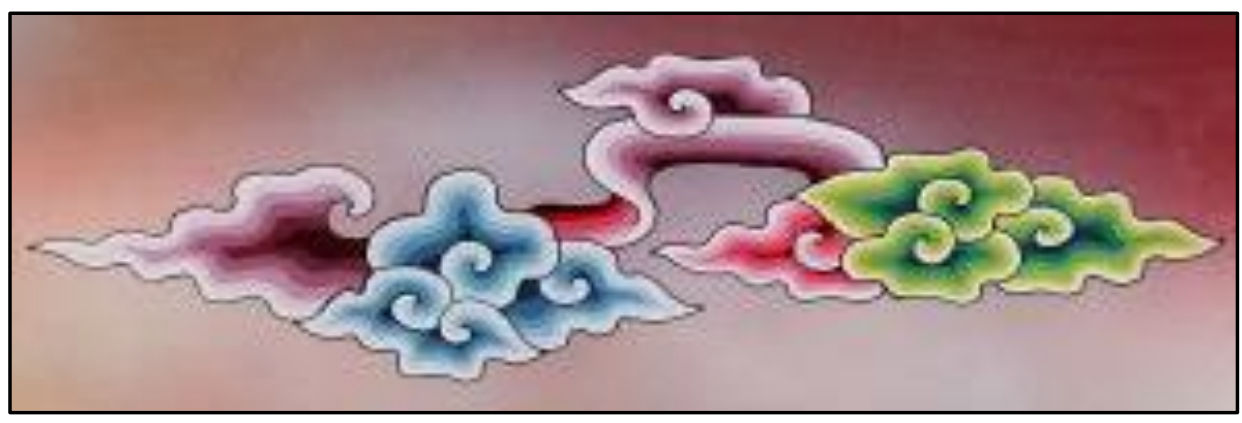

Fig. 3. Mega Mendung Motif in Semar Calligraphy Glass Painting (Rukiah 2019)

While the mega mendung motif is also found at the bottom of the paintings that form the rocks with gradations of red, blue, and motif motifs in the middle of the painting colored gradations of yellow, green, blue, and red, this serves as the footing of the figure of Semar, look at Figure 4.

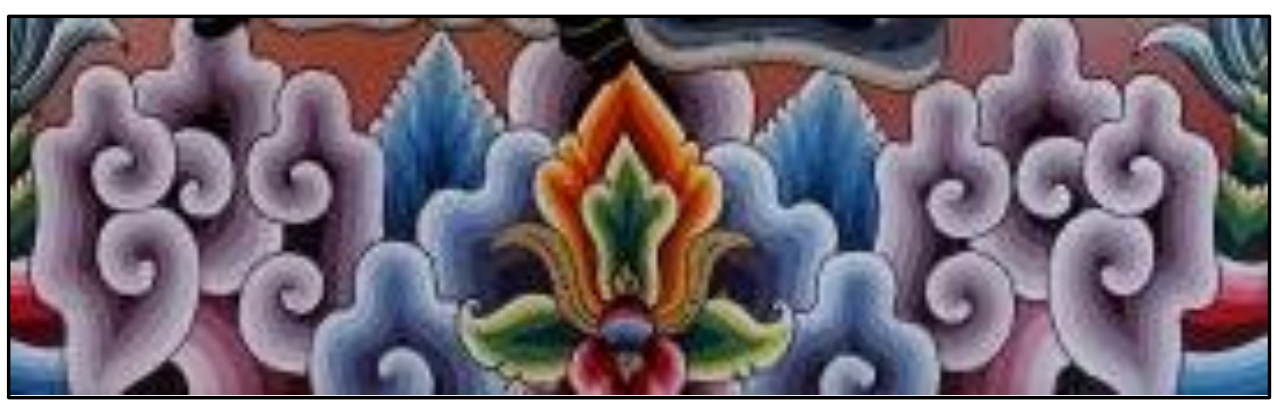

Fig. 4. Mega Mendung motif and wadasan in Semar Calligraphy Glass Painting (Rukiah 2019)

- Isen (stuffing) is a filler element whose function is to decorate the main motif and interlude (supporting) motif. Semar's calligraphy glass painting isen motif contained in Semar's figure, namely: 
1) on Semar's black body containing Arabic calligraphy, which contains two shahadat sentences, calligraphy is colored with black gradation with a golden prada outline. The meaning of Semar Hitam's body is to symbolize the permanence and calligraphy of these two shahadat sentences that need to be believed and held firmly continuously until humans die. Allah and the Prophet Muhammad, and their teachings bring themselves to be fair and lasting, see Figure 5.

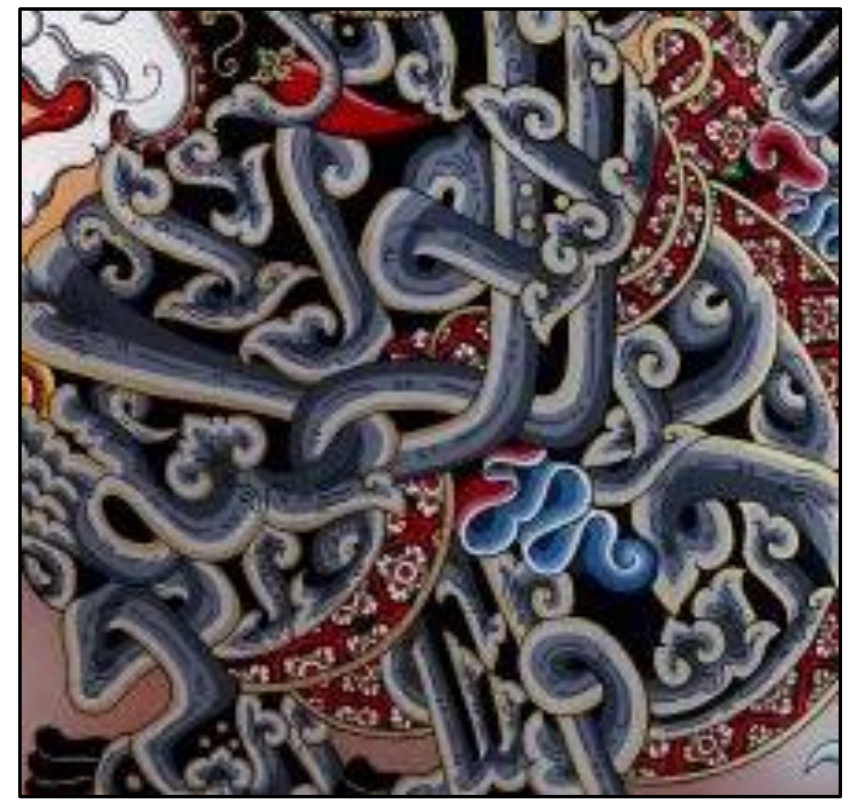

Fig. 5.Glass Painting Semar Calligraphy (Semar Body) (Rukiah 2019)

2) Semar's face is depicted white with red lips with black lines that form the nose, eyebrows, eye shape, and cheek strokes, meaning the white Semar face with black lines symbolizes something created by God in pairs, see Figure 6.

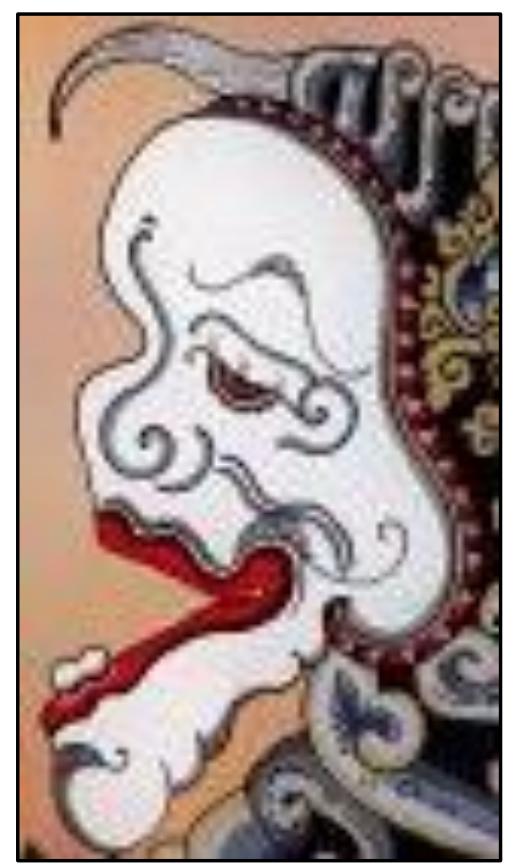

Fig. 6. Glass Painting "Semar Calligraphy" (Semar Face) (Rukiah 2019) 
The message to be conveyed by Kusdono as a painter is the character and nature of the Semar puppet that illustrates human nature in this world. Semar in this painting is depicted as a symbol of "divinity" in this painting (Semar) is not a "picture of God," but only serves as a symbolic language or conception of aspects of "divinity of the almighty." The wayang Semar figures in wayang are panakawan or tutors who memayu hayunging bawana and sepi ing pamrih, rame ing gawe. Wayang Semar is one of the shadow puppet figures given God's nature or god or god to defeat God's power or Betara Guru.

\section{Conclusion}

Wayang is the most widely spread traditional art performance in Indonesia. Wayang is an expression of community values that shape the cultural identity of a community, especially Java. In Indonesian puppets, especially in Java, Sunda, and Bali, there are special figures called Punakawan. One of Punakawan's famous figures is Semar, and it is essential in Javanese and Sundanese wayang. Semar figures and the puppets are also applied to several visual forms such as batik, glass painting, calligraphy, etc. Cirebon glass painting is one of the propaganda media. Kusdono's Cirebon glass painting with the theme Semar Calligraphy uses Semar as an object because Semar in puppets is known as someone who always does good, keep the truth and always obey his teachings, also the use of Arabic calligraphy - painting Semar Calligraphy a combination of moral and theological power, namely a visual vehicle in the form of puppet and calligraphy as a non-figurative aesthetic expression. This painting is examined using the iconography of Cirebon glass painting Semar Calligraphy. This is called figural calligraphy because it combines figural motifs with calligraphy elements through various ways and styles. This painting is examined using iconography that discusses the visual elements in the painting. In this Cirebon glass painting, it uses mega mendung and wadasan motifs known as Cirebon batik motifs. The colors used to use coastal colors because Cirebon's geographical location is close to the beach. The aesthetic meaning of Cirebon glass painting can be seen from the shape or structure composed of motifs fulfilling the field of painting, including (a) The main motive, in this painting the main motive is the Semar figure itself because, for Javanese people, the Semar figure is made as a guardian, role model, and guidance. Each Semar teaching contains life guidance, (b) Motive filler (interlude), this motif serves as a complement to the main motive because it is also called a supporting motif. Supporting motifs are found in the mega mendung motifs that are located at the top and bottom of paintings and wadasan motifs as supporters, (c) Isen (filling motifs), these motifs fill in from the main motifs. This motif is a two-sentence creed found on Semar's body, which symbolizes the teachings humans bring to death. Semar's conception has represented the kalimat shahadat creed as a whole, namely as a conception of God.

\section{References}

Anisah, Aeiny Nur. 2008. "Konstruksi Sosial Nilai Psikologi Punokawan Semar Pada Masyarakat Jawa." Universitas Muhammadiyah Surakarta. Available at: Google Scholar

Denzin, Norman K, and Yvonna S Lincoln. 2011. The Sage Handbook of Qualitative Research. Sage. Available at: Google Scholar

Dharsono, K Sony. 2016. Kreasi Artistik Perjumpaan Tradisi Modern Paradigma Kekaryaan Seni. Jati-Jaten Karanganyar: Citra Sain. Available at: Google Scholar

Endraswara, Suwardi. 2006. Metode, Teori, Teknik Penelitian Kebudayaan. Yogyakarta: Pustaka Widyatama. Available at: Books Google

Hadiwijono, Harun. 1983. Konsepsi Tentang Manusia Dalam Kebatinan Jawa. Jakarta: Penerbit Sinar Harapan. Available at: Google Scholar

Hardjowirogo. 1982. Sejarah Wayang Purwa. Jakarta: Balai Pustaka. Available at: worldcat

Koentjaraningrat. 1990. "Pengantar Ilmu Antropologi.” Jakarta: PT Rineka Cipta. Available at: Google Scholar

Kresna, Ardian. 2012. Punakawan: Simbol Kerendahan Hati Orang Jawa. Yogyakarta: Narasi. Available at: Google Scholar 
Muhadjir, Noeng. 2000. Metode Penelitian Kualitatif Edisi IV. Yogyakarta: Rake Sarasin. Available at: perpusnas

Mulyono, Sri. 1989. Apa Dan Siapa Semar. Jakarta: CV. Haji Mas Agung. Available at: Google Scholar

Panofsky, Erwin, Albrecht Dürer, and Giorgio Vasari. 1955. Meaning in the Visual Arts: Papers in and on Art History. Vol. 39. Doubleday Garden City, NY. Available at: Books Google

Probosiwi, Probosiwi, and Yuni Hastuti. 2019. "Visual Aesthetics Understanding of Elementary Students in Creating the Artworks.” International Journal of Visual and Performing Arts 1 (2): 80-89. doi: 10.31763/viperarts.v1i2.64.

Putra, I Made Diana Dwi, I Wayan Sudiarta, and I Gusti Ngurah Sura Ardana. 2014. "Ikonografi Figur Punakawan Wayang Kulit Cenk Dan Blonk.” Jurnal Pendidikan Seni Rupa Undiksha 4 (1). doi: 10.23887/jjpsp.v4i1.2110.

Rukiah, Yayah. 2016. “Kajian Estetika Poster Tadanori Yokoo-1965.” Jurnal Desain 3 (03): 198-212. doi: 10.30998/jurnaldesain.v3i03.716.

_. 2019. "Visual Elements of" Semar Calligraphy" on Cirebon Glass Painting of Kusdono’s Work.” In IICACS: International and Interdisciplinary Conference on Arts Creation and Studies, 1:43-47. Available at: Google Scholar

Sunarto. 1997. Seni Gatra Wayang Kulit Purwa. Semarang: Effhar \& Dahara Prize.

Waluyo, Eddy Hadi. 2006. Lukisan Kaca Cirebon Dari Masa Awal Hingga Kini. Bandung: Puslitbang Pendidikan Seni Tradisional LIPI. Available at: Google Scholar 